\title{
The natural resource management to support tourism: A traditional knowledge approach in Pegunungan Arfak Nature Reserve, West Papua, Indonesia
}

\author{
LUKAS YOWEL SONBAIT ${ }^{1}$, HOTLAN MANIK ${ }^{1,2}$, HERMANUS WARMETAN ${ }^{3}$, \\ YUSTINA LINA DINA WAMBRAUW ${ }^{4}$, MEKY SAGRIM ${ }^{4}$, DONY ARISTONE DJITMAU ${ }^{3}$, \\ JACOBUS WANGGAI ${ }^{1}$, BERNADUS BENNEDICTUS RETTOB ${ }^{1}$, AGUSTINUS MURDJOKO ${ }^{3,5, \bullet}$ \\ ${ }^{1}$ Faculty of Animal Science, Universitas Papua. Jl. Gunung Salju, Manokwari 98314, West Papua, Indonesia \\ ${ }^{2}$ Faculty of Animal Husbandry, Universitas Padjadjaran. Jl. Bandung-Sumedang Km 21, Jatinangor, Sumedang 45363, West Java, Indonesia \\ ${ }^{3}$ Faculty of Forestry, Universitas Papua. Jl. Gunung Salju, Manokwari 98314, West Papua, Indonesia. `email: agustinus.murdjoko.papua@ gmail.com \\ ${ }^{4}$ Faculty of Agricultural, Universitas Papua. Jl. Gunung Salju, Manokwari, 98314 West Papua, Indonesia \\ ${ }^{5}$ Research Center of Biodiversity, Universitas Papua. Jl. Gunung Salju, Manokwari 98314, West Papua, Indonesia
}

Manuscript received: 13 August 2021. Revision accepted: 26 September 2021.

\begin{abstract}
Sonbait LY, Manik H, Warmetan H, Wambrauw YLD, Sagrim M, Djitmau DA, Wanggai J, Rettob BB, Murdjoko A. 2021. The natural resource management to support tourism: A traditional knowledge approach in Pegunungan Arfak Nature Reserve, West Papua, Indonesia. Biodiversitas 22: 4466-4474. Pegunungan Arfak Nature Reserve (PANR) is administratively located in three districts of West Papua, namely Manokwari, Manokwari Selatan, and Pegunungan Arfak that has diversity of protected flora and fauna. Therefore, it is crucial to study the local products for the development of ecotourism models based on local wisdom in supporting the potential economy of communities in the Pegunungan Arfak reserve. The data were obtained from direct interviews with communities around the nature reserve area through related government agencies in Manokwari District. The finding of this research highlighted that local people in Pegunungan Arfak (the Hatam-Moile sub-tribe) still use traditional knowledge for their livelihood. Most of the activities were the utilization of natural resources such as flora and fauna. They understand how to manage the natural resource to earn economic benefit along with the implementation of their traditional concept to promote the sustainability of nature. The biodiversity and socialcultural richness of local people in Pegunungan Arfak have value to be developed together with traditional ecological knowledge in sustainable nature management where local people earn benefits and nature is conserved simultaneously.
\end{abstract}

Keywords: Ecotourism, endemic species, ethnobiology, New Guinea

\section{INTRODUCTION}

Pegunungan Arfak Nature Reserve (PANR) is a conservation area containing high biodiversity which was the first biological collection site in Papua developed by European Lesson Researchers, Beccari and Albertis. The results of the FAO survey in 2005 found more or less 2.770 species of both flora and fauna. The most popular and sought-after species of animals include various species of butterflies. The species of bird-wing butterfly (Ornithoptera spp.) have become the international butterfly collector hunt in this region. The diversity of butterflies is still quite high, including six species of wing-bird butterflies (Ornithoptera arfakensis, O. rothschildi) that attract the attention of researchers and foreign tourists when visiting the PANR. In the PANR area, there are an estimated 110 mammal species with 44 species that have been recorded, 320 species of birds, of which 5 (five) are endemic to the Arfak-Tambrauw Mountain Area such as, Arfak astrapia (Astrapia nigra), parotia (Parotia sefilata), and namdur polos (Amblyornis inornatus). In addition, the Pegunungan Arfak are mountainous areas covered by 68,325 hectares of tropical rain forests (Kartikasari et al.
2012; Pattiselanno and Lubis 2014; Sutarno et al. 2017; Manangkalangi et al. 2019; Pattiselanno et al. 2019).

This biodiversity can be seen as a renewable natural resource that can be relied upon as the support for conducting development and ecological conservation (Mittermeier et al. 1998; Alamgir et al. 2019). Besides that, biodiversity is very useful for traditional societies that are multi-ethnic with various cultures and various biological product needs (Pattiselanno and Krockenberger 2021). Thus, the Pegunungan Arfak reserve area is very potential as a place for visiting the ecotourism attraction development in Manokwari District. The local wisdombased tourism area management model is an effort to strengthen the local economy and natural resource conservation in Manokwari District. People's core tourism emphasizes the management of tourist areas demanding community participation in various sectors. One of the goals during tourism activity is to ear economic benefit, but the ecological condition in the management area must be taken into account, resulting in the balance of the economic and ecological process. Understanding of the economic perspective in the management of tourism areas economic factors play an important role given that without economic benefits, tourism business actors, including people in 
tourist destinations, will not be interested in participating in tourism development (Arobaya et al. 2020). The ecological perspective means that in many ways, tourism relies on its main capital in the environment, both natural environment and cultural environment. Consequently, the ecological elements that are the main capital of tourism must be preserved to function sustainably. Thus, it is necessary to apply the model as a form of the trial conducted on the model's socialization, raise public understanding of tourism economic perception, and grow public understanding of the ecological standpoint. The implementation of the ecological model in Manokwari District is likely to produce lessons for the improvement of the area development (Pattiselanno 2016). The growth of tourism can provide more value not only to the environment and the economy of the local community but also to the social welfare of society in general. Despite the potential possessed by the PANR region, this region has problems due to habitat degradation, collection of eggs, poaching, and the absence of accurate data on the number of the existing endemic animals.

Local people (99\% native to the Arfak tribe), who are in the vicinity of the nature reserve, still use wood for their livelihoods and clear the forest for cultivation leading to habitat damage and decline in animal populations. Traditional knowledge has been part of local community activity, where it must be figured out to support the development of nature management (Santos et al. 2019; Benner et al. 2021). The areas of West Papua, including Pegunungan Arfak consist of high biodiversity and cultural aspects. Indeed the local people have utilized the natural resources for centuries to support their livelihood (Sutarno et al. 2017). For example, the diversity of animals and other ecotourism potentials in the region are promising selling points for the economic improvement of the community through ecotourism. The economic benefit from ecotourism allows local communities to abandon hunting and illegal logging practices and maintain local wisdom. Therefore, it is necessary to conduct basic research to figure out the local commodity for the development of ecotourism models based on local wisdom in supporting the potential economy of communities around the Pegunungan Arfak reserve, Manokwari district. The research explored the traditional knowledge in this area that has been applied for generations to utilize natural resources. The concepts would be valuable to be integrated with government programs in nature management based on traditional knowledge.

\section{MATERIALS AND METHODS}

\section{Study area}

The study was conducted from May to August 2017 in Syoubri village located at $133^{\circ} 54^{\prime} 40.67^{\prime \prime E}, 1^{\circ} 66^{\prime} 26.68^{\prime \prime S}$ and in Kwau village at $133^{\circ} 54^{\prime} 15.56 " \mathrm{E}, 1^{\circ} 10^{\prime} 57.61^{\prime \prime S}$, in the Sub-district of Minyambou, the District of Pegunungan Arfak, West Papua Province, Indonesia. It is the buffer zone of the PANR with an area of 68,325 hectares, located in the territory of the Bird's Head of West Papua Province. Syoubri village and Kwau have a distance of around $45 \mathrm{~km}$ from Manokwari city of West Papua Province and about 62 $\mathrm{km}$ from the Anggi capital of the Mountain Sub-district Arfak with an elevation of the research study of around $1700 \mathrm{~m}$ a.s.1. The location of research in Syoubri village and Kwau can be seen in Figure 1.
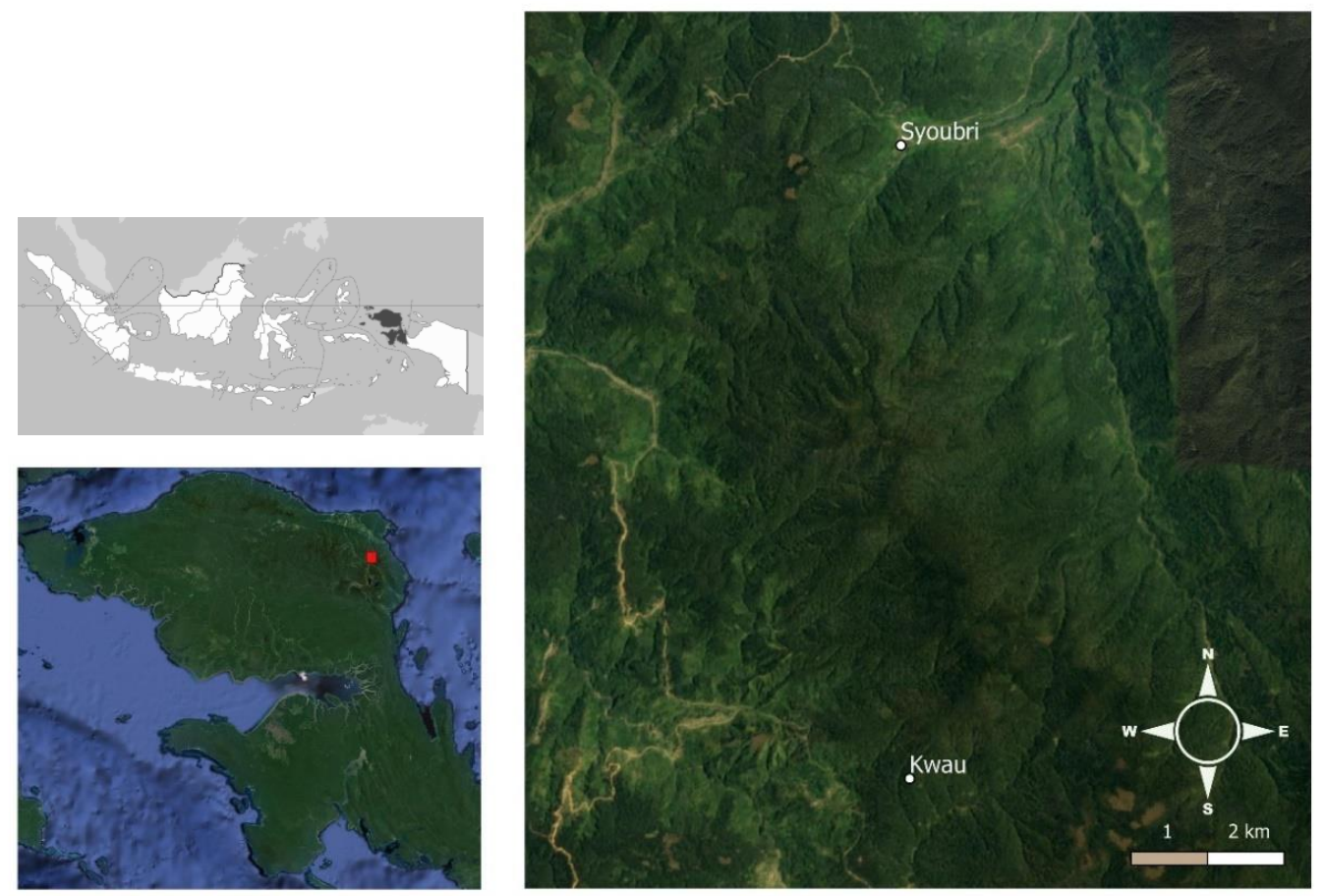

Figure 1. Research location of Syoubri and Kwau villages (white dots on the main map), Sub-district of Minyambouw, District of Pegunungan Arfak, West Papua Province, Indonesia 


\section{Procedures}

We collected data by conducting semi-structured interviews and site visits as direct observations. The interview was started by asking the key informants, namely, head villages of Syoubri and Kwau, elderly people, and landowners, to collect socio-culture data and traditional ecological knowledge and to obtain eligible informants during data collection (Pawera et al. 2017). The data of socio-culture were name, profession, age, gender, education, and position in social structure, while traditional ecological knowledge was the utilization of flora, fauna, and the forest. We also asked how they traditionally managed the area as a tourist destination when they prepared accommodation, local guide, souvenir, and their awareness of the sustainability of nature. Besides, we gathered the information of those who have already assisted during tourism development in this area, such as non-governmental organizations (NGOs) and local government. Moreover, the process of assistance was also figured out to gain information. We collected the information using written questions, and we also requested them to show the tourist places.

\section{Data analysis}

The data were analyzed by examining them directly in the field, setting conclusions and assumptions, and recording with ethnozoological and ethnobotanical descriptions. The explanations were also illustrated by means of images that were taken during the site visit. The result of the interview would be matched with those images to find out the traditional ecological knowledge during tourism management. The images during data collection comprise the story of local people's activities and can be used to visually validate the information (Castleden et al. 2008; Peterson et al. 2019).

\section{RESULTS AND DISCUSSION}

\section{The local concept for natural resource management}

Residents living in Kwau and Syou villages are native to Arfak from the Hatam-Moile sub-tribe. They live on the move, participating in gathering and hunting activities in their clan's customary regions. They formed the first settlement in Mokwam village from their home village in Minyambouw. Kwau village was formed because when the access to the highway was not opened, Kwau village was the closest exit for people from Warmare to Manokwari City. The communal formed another new settlement in Syoubri hamlet, which was closer to the main road. The formation of these new villages is thought to be closely related to their communal customary land tenure system based on the clan. So, each village tends to be occupied only by several clans whose customary lands are located side by side. Settlement patterns of village formation are so closely related to the land distribution system with the concept of Igya Ser Hanyob, which means "let's stand guard the boundaries".

The tourist attraction in the village are unique landscape, and unique flora and fauna, and culture. Therefore, the introduction of orchid cultivation and other types of ornamental plants are considered. Thus, the conservation consists of ex-situ and in-situ conservation of endemic orchids. This species of orchid is unique, so the floriculture will impact the endemic orchid by the presence of introduced species of orchids and other ornamental plants.

The most famous tourist attraction in this village is the smart bird's nest (Namdur), constructed from twigs, flowers, and other colorful materials and a variety of birds of paradise. Based on the guest book in the guest house (homestay), bird researchers from various parts of the world have come to Kwau villages, such as bird researchers from America, England, Germany, Sweden, Netherlands, Africa, Australia, China, Italy, Singapore, France, and others. Lodging rates for foreign tourists are IDR. 250,000 per day/person, domestic IDR. 200,000, and service guests IDR. 100,000. In addition to lodging rates, rates for tourist guides are also set at IDR. 250,000 / day. In addition to the homestay, the local community has also built an observation lodge for smart birds and birds of paradise with a rate of IDR. 100,000 per observation. The rates of homestay and observation cottage are determined by the local community based on the birds' musicality. Income from sales of homestay services and observation huts is managed for the village treasury, church cash, donations for the education of school children, and the manager of homestays and observation huts. Several key figures of the Kwau village community say that the community has realized that smart bird and Cenderawasih tours can bring the village's income from the bird-watching homestays and huts, as well as tourist guide services.

\section{Traditional ecological knowledge}

The Arfak and Hatam-Moile communities in particular are familiar with the distribution of forest areas based on natural biophysical characteristics such as elevation, topography, and climate and the rules for their use. The division of this forest area includes the concept of Igya Ser Hanjob, from the Hatam language, which means "we stand guarding the limits". This concept is a rule and warning for the large tribal people of Arfak, which consists of the sub-tribes Hatam, Meyakh, Moile, and Sougb. For the people of the Arfak tribe, "guard and do not cross the boundaries that are determined when utilizing forest products". Finally, the concept of Igya Ser Hanjob is interpreted broadly by the community as the slogan "let's keep the forest for the common good".

The Igya Ser Hanjob system is divided by categories of zoning, viz. Tumti, Bahamti, Nimahanti, and Situmti. Igya Ser Hanjob zoning is a traditional conservation technique that has been applied by the Arfak community for generations. The area is divided into 4 zones based on the nature and characteristics of the land (Figure 2), namely: (i) Situmti is a zone used by people living and gardening; (ii) Nimahanti is a zone that was previously opened by the community to carry out gardening activities, and after the harvest is over, the land will be abandoned. In this zone, there are many ferns and fast-growing plants. This zone is a secondary forest; (iii) Bahamti Zone is a zone that is overgrown by large trees. This is a zone that can be converted into a new zone because the forest floor is not completely covered with moss. In this zone, there are still primary forests; and (iv) Tumti zone (Figure 3). This zone is generally located at the top. Because this is a primary forest and the floor is covered with moss, arresting violators in this zone cannot be done. 


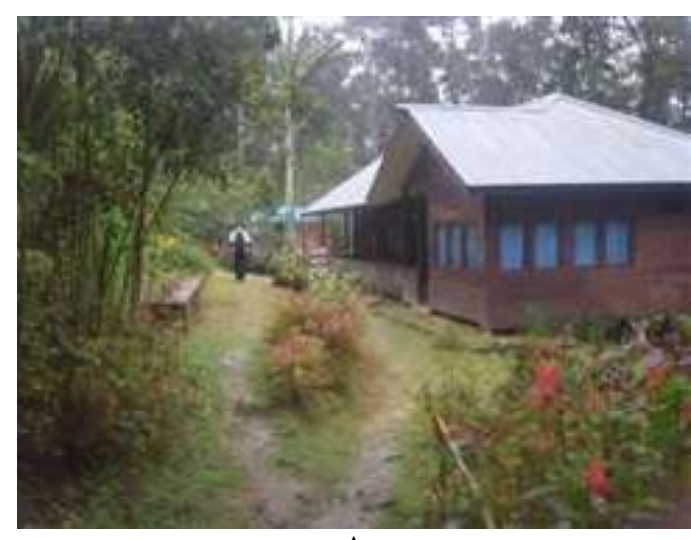

A

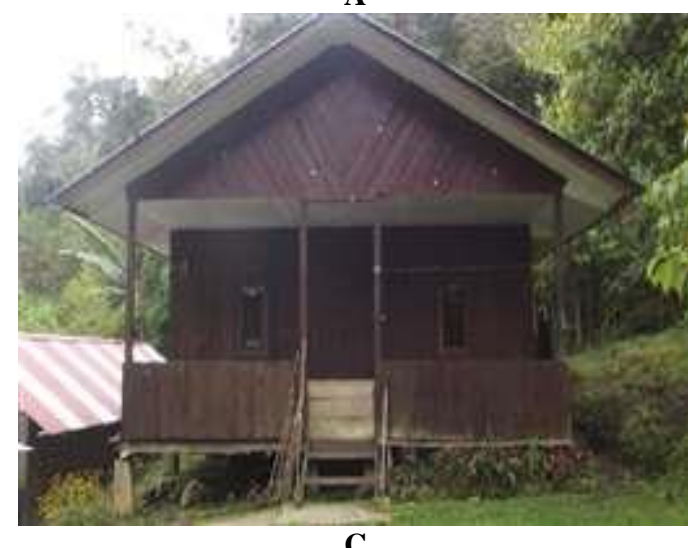

C

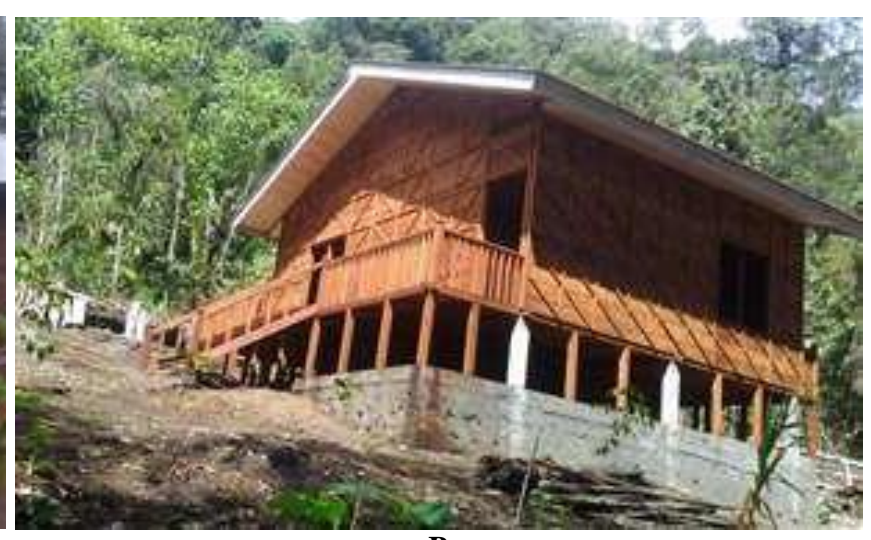

B

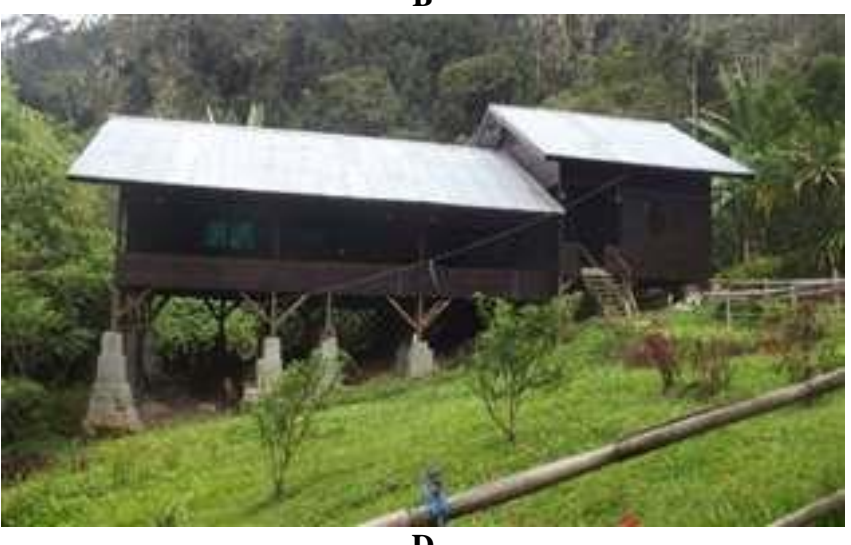

D

Figure 2. Lodging facilities for domestic and foreign tourists. A. Homestay in Kwau hamlet 1 (IDR 50,000/day), B. Homestay in Kwau hamlet 2 (IDR 200,000/day), C. Homestay in Syoubri hamlet 1 (IDR 100,000/day), D. Homestay in Syoubri hamlet 2 (IDR 100,000/day)

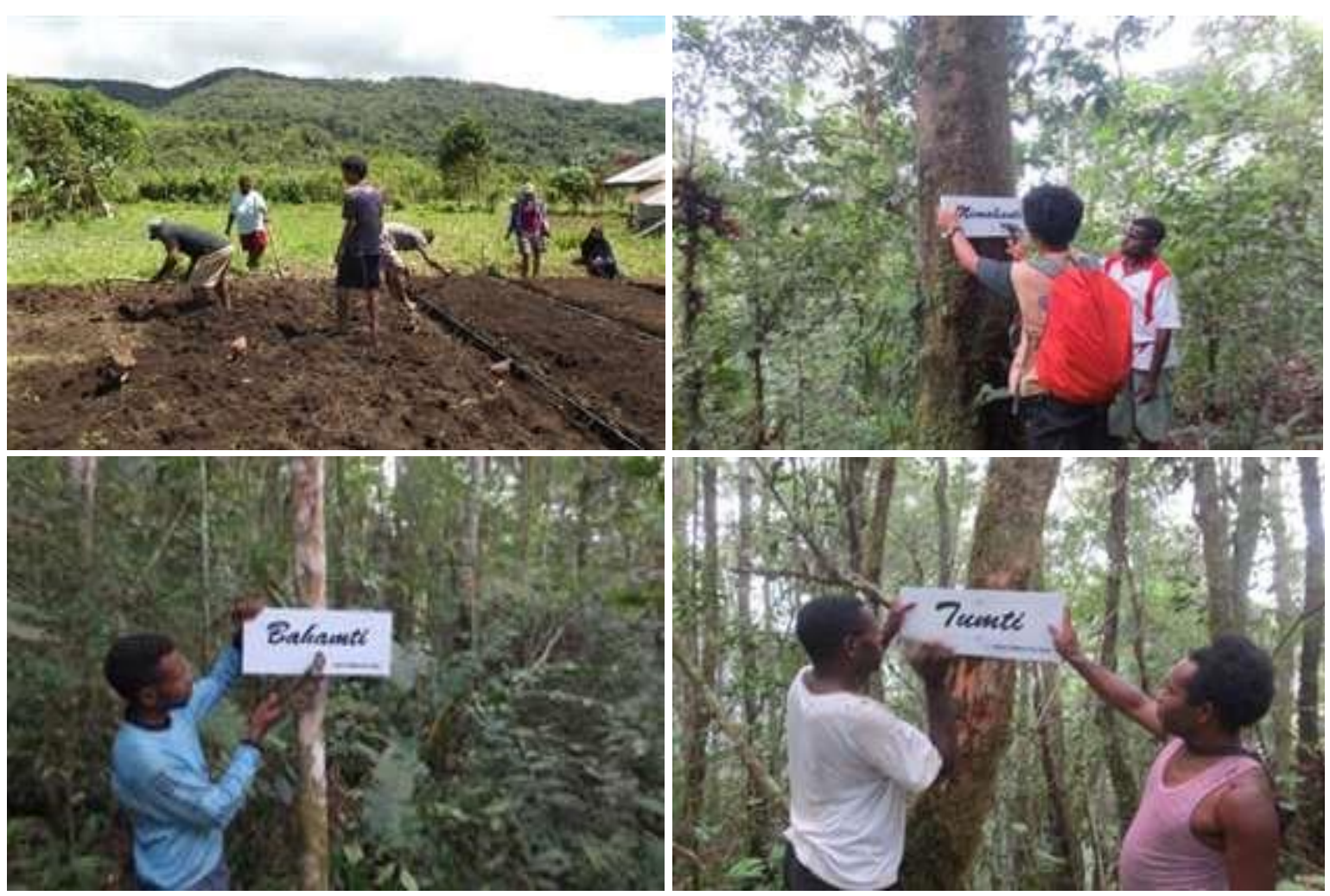

Figure 3. Forest distribution system based on biophysical characteristics in the Arfak community 
The Arfak community generally divides the forest zone (bigbebei $=$ forest) into three parts, namely: (i) Bahamti is a primary forest area whose location is higher than the community settlement. This foggy area has a cold temperature. In this area, it is not allowed to build villages and gardens. This area is the location for taking certain types of timber, pandan leaves, and rattan. The timber taken in this area is used as columns, the bark as wall material, the pandan leaves as roof material, the fruit as a repellent, and the small rattan as binders in the construction of a thousand-foot house, a traditional house with elevated floor supported by many columns; (ii) Nimahamti is a forest area that is very moist and overgrown by moss both on the ground and in trees. This area has a topography that is difficult to reach from the village, and cold temperatures, so not all plants can thrive, especially food crops; (iii) Susti is a secondary forest area that was previously used as a garden area that has been abandoned and has grown into a forest again. Ex-plantation areas with cleared land can be categorized into sustenance areas. After having been abandoned for 4 years, the diameter of the tree has reached an average of $40 \mathrm{~cm}$ with a total tree height of $8 \mathrm{~m}$. This area is a source of wood for fuel (firewood) and a garden fence. The species of woody plants that dominate this area are Piper spp. and Dodonaea viscosa. Dodonaea sp. There are two types of plants grown in this area, namely red bark and black bark. This area is divided into 2 parts, namely: Susngoisi (former gardens that have been abandoned for a year, and the plant buds have begun to grow); and susmahan (former gardens that have been left for more than five years, and the plants have reached a diameter of $>$ $30 \mathrm{~cm}$ ). Arwob wood (Dodonaea viscosa) with a small diameter that is used to build a thousand-foot house is also taken from this region.

In addition to using plants, the ethnic group of Kwau and Syoubri village and its surroundings also utilize animals to fulfill their daily needs, such as food and health needs. At present, local, domestic and foreign tourists who are looking for the native habitat of Arfak plain birds and black souvenirs will come to the Mokwam plains. This is what causes the community to gradually, with assistance from the government and NGOs, develop area into a natural tourist destination. Various species of birds that were once hunted animals are now no longer the target of the game. Currently, in forest areas that used to be hunting areas, with the deliberation of all villagers and determined as village decisions, hunting is not permitted in any form and any type of hunting equipment.

Cultural norms and values owned by the community are realized through traditional ceremonies, dances, and handicrafts. Traditional ceremonies are a form of public expression of joy and sadness. The community's joy can be expressed during the reception ceremony and wedding parties, while sadness is expressed when grief occurs. The best-known dance of the Hatam-Moile tribe is the Tari
Tumbu Tanah (traditional dance). This dance is performed in conjunction with traditional ceremonies such as guest reception, wedding, and death ceremonies. The dance is accompanied by songs whose lyrics are in the form of rhymes selected according to the type of celebration.

This Tumbuk Tanah dance is very well known in Manokwari and throughout the bird's head region in West Papua Province. This dance is interesting and unique because its movements mimic the movements of snakes above the ground. This dance is also known as snake dance because, for them, snakes are their symbols of greatness. The movements in the Tari Tumbu Tanah resemble snakes following the rhythm of the song sung by the dancers (Figure 4).

This Tari Tumbu Tanah spreads throughout the bird's head region, Papua, and it is done especially by the large Arfak tribe in Manokwari (Mnu Kwar), which consists of several sub-tribes, namely Hattam, Meyakh, Sough, and Moile. There are also several tribal clusters. including Karon, Saukorem to Ayamaru, Aitinyo, and Aifat in Maybrat and South Sorong Regencies. Generally, these tribes know Tari Tumbu Tanah, only in different versions and methods according to the character of each tribe in the Tanah Burung. The Hattam people call Tari Tumbu Tanah in the local language Ibihim, for the Meyakh people, Muuka, while the Sough people Lenyohora. For them, this dance is usually held for greeting guests, weddings, the victory of the war, and others.

The most popular crafts made by the people in Mokwam village and its surroundings are noken that are made mostly by women. Noken raw materials come from herbaceous plants (local name: konica) which reach 3-4 meters high and fiber from pineapple leaves. Noken raw materials derived from herbaceous plants are from old konica stems taken for about $1 \mathrm{~m}$ in length and then dried to dry and then taken by the skin. Then the skin is separated according to the fiber groove and then twisted in a circle until it forms a thread and is ready to be used as raw material for making noken. The other raw materials are pineapple leaves. The work process begins with choosing pineapple leaves that are of medium age (not too old and not too young). The selected leaves are then slowly scrubbed on the outside and dried. Then the fibers are separated according to the fiber path and then twisted until they form strands of yarn that are ready to be used as raw materials for noken. In addition, the customary wedding procession starts from the proposal, payment of the dowry, wedding ceremony, and the ceremony take the bride to the male side. The dowry that applies to the people of Hatam-Moile is kain timor, toba cloth, paseda (clam bracelets), large hanging beads, shop cloth, sarong fabric, pigs, and large weapons. At present, the types of dowry have been given in the form of money, cattle, wall clocks, radio, and cars. The bride who has just been paid can be delivered to the family of the man. 


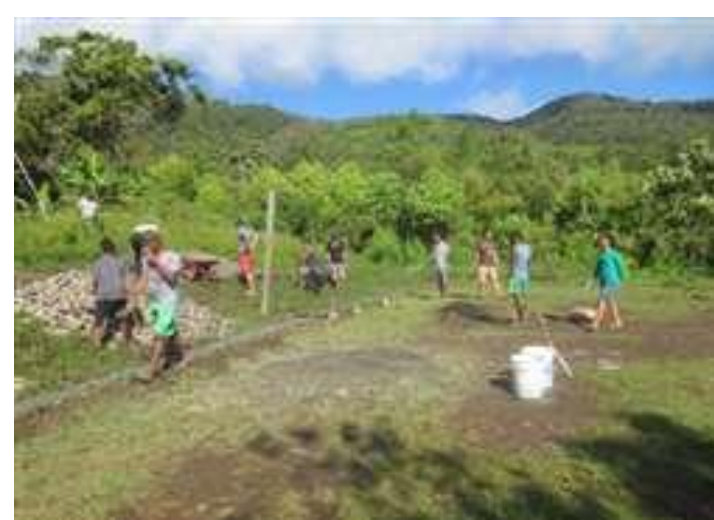

A

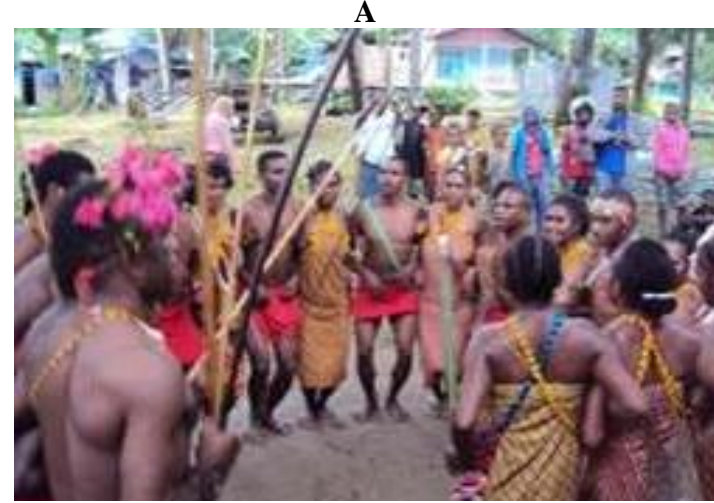

C

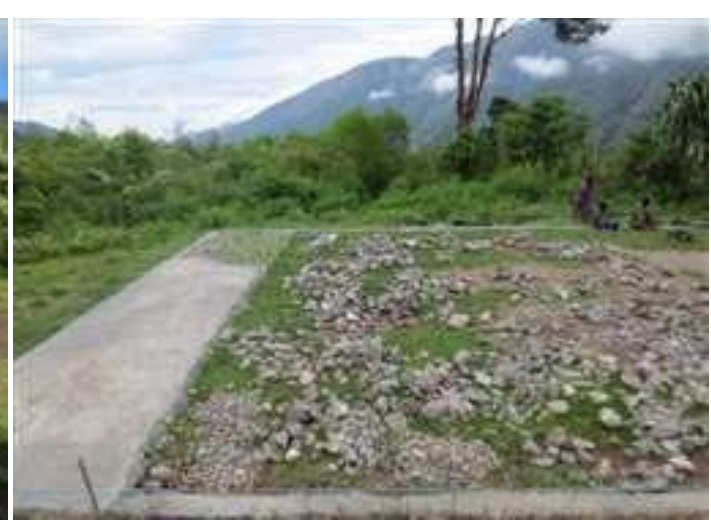

B

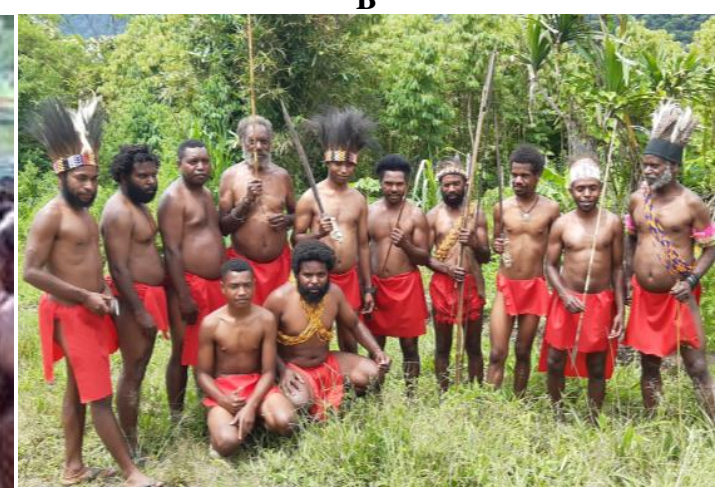

D

Figure 4. Ceremonial activities: A-B. Community activities make traditional ceremonies; C. The Tari Tumbu Tanah; D. The group of Tari Tumbu Tanah

According to one of the Wonggor clan woman (Wonggor clan knows religion, i.e., Christianity), they did not request a dowry to the man who wanted to woo the Wonggor clan. Instead, the man who proposed to the Wonggor clan was obliged to live in the women's clan. This was pioneered by Mr. Benyamin Wonggor, who introduced Christianity to the Arfak tribe, especially on the Mokwam plain. People use signs that come from plants as a marker. For example, in a forest area where hunting and other damaging activities are prohibited, the community gives signs: Riyepa/igyok monga (snares), meaning that you cannot trap wildlife; Nimaia, in the form of bamboo tied with ropes, meaning that they cannot hunt with weapons; Bamboo is split and hung at the top, meaning that the offender will get a life punishment.

Another example, if people give a sign to a building or land using bamboo, especially bamboo with a small size, it means a very strong warning for anyone who deliberately violates the prohibition sign. If the violator of the ban is caught red-handed, then he or she will be processed customarily. The party making the prohibition sign is the party that determines the number of customary fines that must be paid by the violator. The type of fine that the offender must pay, according to Hatam-Moile culture, is in the form of kain timor or pig. Currently, the payment of fines is carried out with the equivalent of money. If the violator accidentally enters the prohibited area, a fine would be the consequence.

\section{Discussion}

The Arfak community is very strict in maintaining customary boundaries between one clan and another. Members of one clan with other members of the clan may not carelessly enter and carry out activities in indigenous territories controlled by other clans without permission from the clan chief who controls customary territories (Sutarno et al. 2017; Pattiselanno et al. 2019). Tourist products in the PANR area are three aspects known as triple-A (Attractions, Amenities, Accessibility). Tourist products can be interpreted as anything that can be sold as a tourism commodity (Sutarno et al. 2017; Carson et al. 2018; Peterson et al. 2019). Tourist attractions consist of the potential of flora, fauna, landscapes, and artificial attractions in the form of art and community culture (Figure 3). Based on the criteria for flora diversity in various ecosystems in the PANR, the quality is very good because FAO survey in 2005 identified 2.770 species of orchids. Various species of wing-bird butterflies (Ornithoptera spp.) which have become the favorites of international butterfly collectors live abundantly in this region. There are six species of wing-bird butterflies $(O$ Arfakensis and $O$. rothschildi) that attract the most attention of researchers and foreign tourists when visiting the PANR (Figure 5). The species of endemic Pegunungan Arfak avifauna had high economic value in their habitat since foreign researchers began to search for them in the early 1990s (Sutarno et al. 2017). In the PANR, it is estimated that there are 110 species of mammals with 44 
species that have been recorded, 320 species of birds, of which five are endemic to Papua which is a huge potential as an ecotourism attraction.

The landscape in the PANR is a combination of various physical components of the ecosystem with the surrounding vegetation, creating a very beautiful panorama as part of the tourist attraction. Landscapes which have an important role in attracting tourists are well-kept in the PANR. One of the attractions in the PANR is the forest that stretches across the region, making the PANR a favorite place of tourists because they can get a sensation or a tough natural challenge when tracking from the starting point of the journey to the finish line (Figure 6). In the mountains, tourists can also enjoy the superior natural beauty of the PANR, especially the smart bird sanctuary, the various species of bird of paradise, and the culture of the community can be used as a support for the development of nature tourism. Cultural tourism attractions that can be sought around the PANR include folk art (Tari Tumbu Tanah).

The supporting factors of tourism here are the natural conditions of this place, including the tradition of local people. Local people in Papua still preserve the traditional knowledge during their life, and some of them have adopted the tradition to the environment (Ungirwalu et al. 2014, 2017, 2019). Moreover, Papua has the highest floristic richness in the world (Murdjoko et al. 2016, 2021b, a; Cámara-Leret et al. 2020; Tawer et al. 2021). The faunal richness has attracted naturalists since centuries ago, leading to the promotion of this place as a tourist destination. The local government has attempted to design the development of tourism programs by providing infrastructure such as roads and socialization to local people to take part.
The local government and non-government organizations (NGOs) have performed the development of tourism for a couple of years. However, possible barriers should be anticipated by identifying both external and internal factors. The social and political conditions in Papua are more or less dynamic, so the local government should guide the local people to support the development. The cost of living in this area is fairly higher than in other cities in Indonesia. Therefore, governmental intervention should be conducted to support the economic condition, so the living cost, particularly in this area would be lower.

\section{Tourism as a potential sustainable product of nature}

The finding of this research revealed that local people in Pegunungan Arfak (the Hatam-Moile sub-tribe) still maintain traditional knowledge for their livelihood support. The biodiversity and social-cultural richness of local people in Pegunungan Arfak should be developed using traditional ecological knowledge in sustainable nature management which provide economic benefit to local people and conserve the nature at the same time. The development of socio-culture in Papua is in agreement with the declaration of West Papua Province programs that have been stated in Manokwari Declaration to conserve nature and culture (Cámara-Leret et al. 2019). Then, the implementation of those programs could promote nature and culture conservation in which the local people could also benefit from such programs. However, the application of tourism activities must be accompanied by Environmental Impact Assessment (EIA) that is controlled by the government. This is very useful to ensure the tourism activity would minimize adverse impact on the environmental conditions, particularly socio-culture and nature.

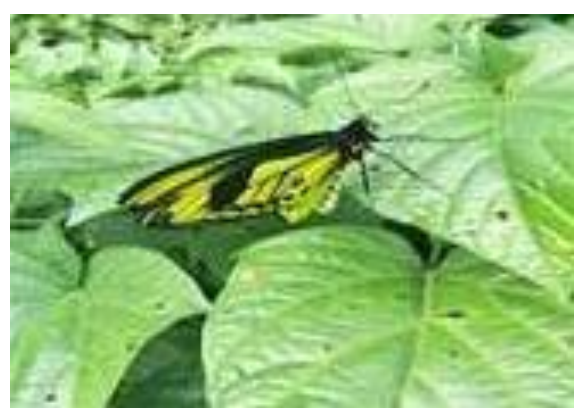

A

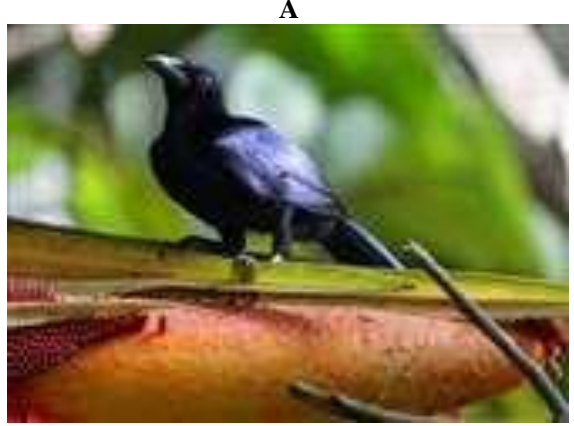

D

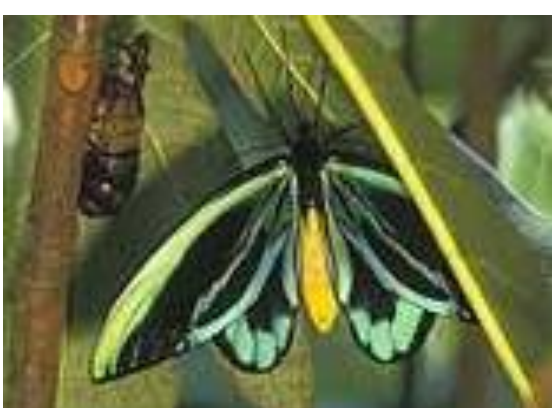

B

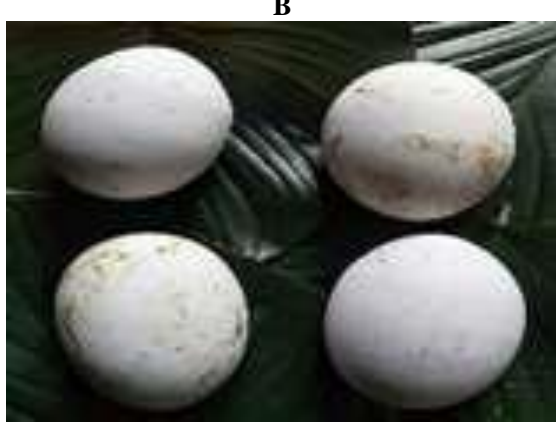

$\mathbf{E}$

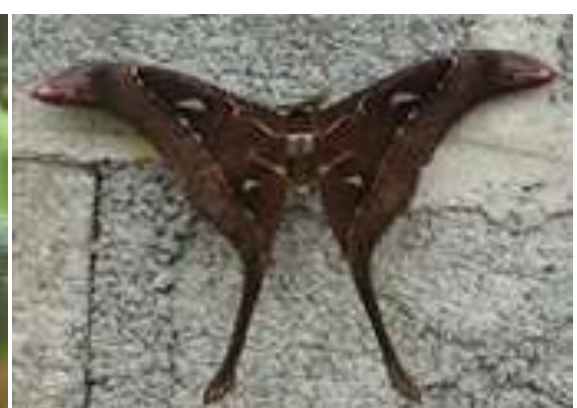

C

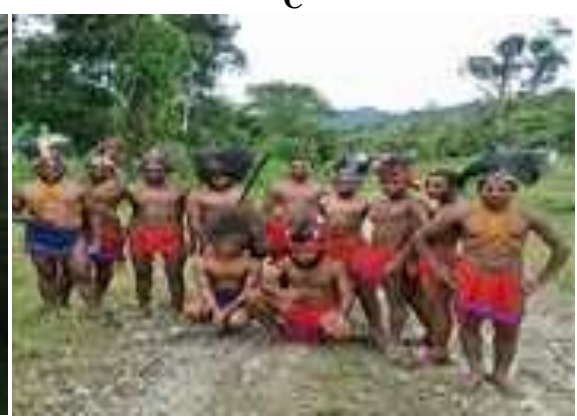

$\mathbf{F}$

Figure 5. Fauna and its use in ecotourism. A. Ornithoptera goliath, B. Ornithoptera alexandrae, C. Hercules moth, D. Arfak astrapia, E. Egg of Wattled brushturkey, F. Bird of paradise and cassowary feather for head accessories 


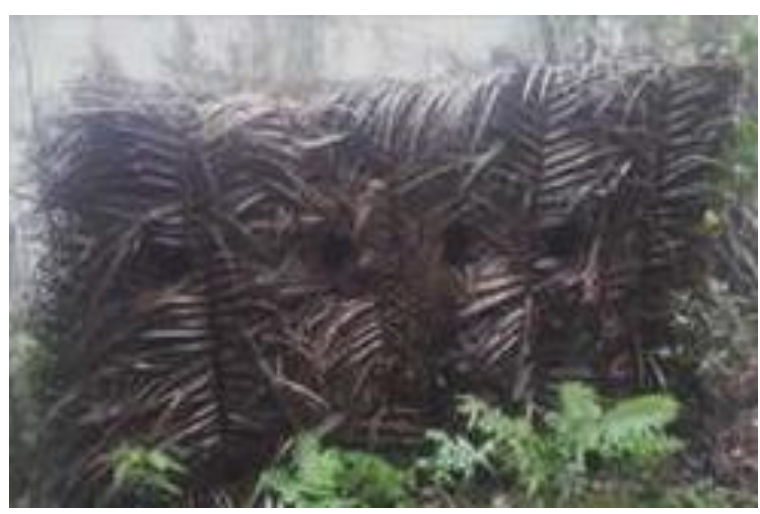

A

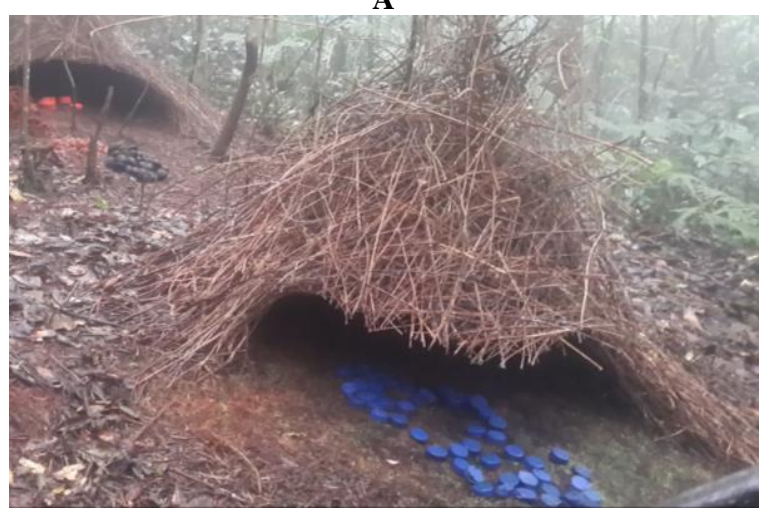

C

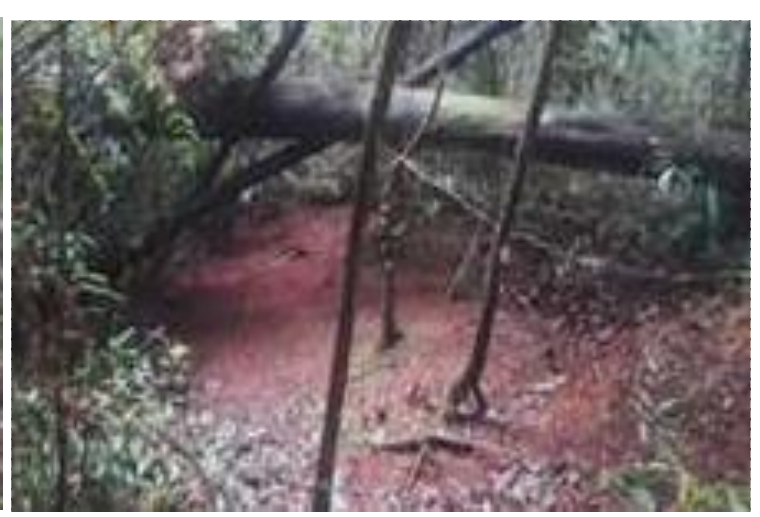

$\mathbf{B}$

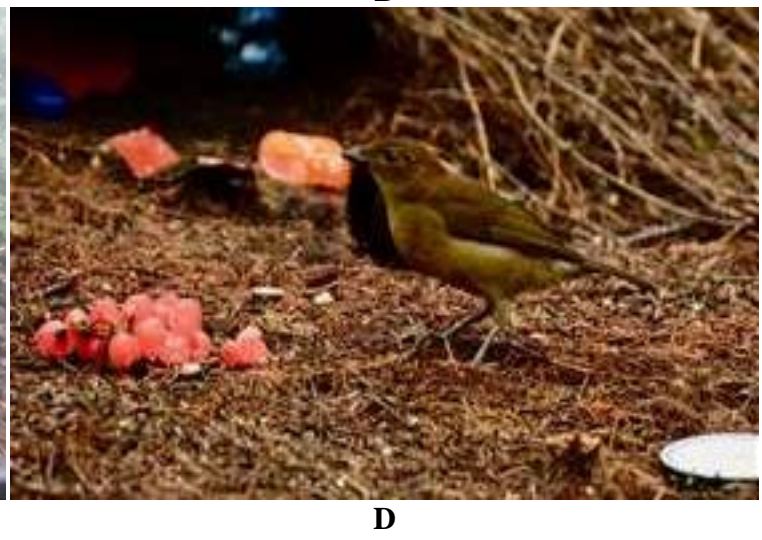

Figure 6. A place of observation for the ecotourism of birds of paradise. A. Place of observation, B. Display area of Vogelkop bowerbird, C. Nest of Vogelkop bowerbird, D. Nest area of Vogelkop bowerbird

\section{ACKNOWLEDGEMENTS}

We thank Pegunungan Arfak District government, people in Syoubri, Kwau, and the Head of Minyambou Sub-district for facilitating the data collection. We are also thankful to the anonymous reviewers for improving this manuscript.

\section{REFERENCES}

Alamgir M, Sloan S, Campbell MJ, et al. 2019. Infrastructure expansion challenges sustainable development in Papua New Guinea. PLoS One 14 (7): 1-20. DOI: 10.1371/journal.pone.0219408

Arobaya AYS, Manusawai J, Pattiselanno F. 2020. Fauna-based ecotourism: A potency for local communities' empowerment in Papua : Review. Seminar Nasional dalam Rangka Dies Natalis ke-44 UNS Tahun 2020 "Strategi Ketahanan Pangan Masa New Normal Covid-19." [Indonesian]

Benner J, Nielsen J, Lertzman K. 2021. Using traditional ecological knowledge to understand the diversity and abundance of culturally important trees. J Ethnobiol 41 (2): 209-228. DOI: 10.2993/02780771-41.2.209

Cámara-Leret R, Frodin DG, Adema F, et al. 2020. New Guinea has the world's richest island. Nature 584 (7822): 579-583. DOI: 10.1038/s41586-020-2549-5

Cámara-Leret R, Schuiteman A, Utteridge T, et al. 2019. The Manokwari declaration: Challenges ahead in conserving $70 \%$ of Tanah Papua's forests. For Soc 3: 148-151. DOI: 10.24259/fs.v3i1.6067

Carson SL, Kentatchime F, Nana ED, et al. 2018. Indigenous peoples' concerns about loss of forest knowledge: implications for forest management. Conserv Soc 16 (4): 431-440. DOI: $10.4103 /$ cs.cs
Castleden H, Garvin T. 2008. Modifying Photovoice for community-based participatory Indigenous research. Soc Sci Med 66 (6): 1393-1405. DOI: 10.1016/j.socscimed.2007.11.030

Kartikasari SN, Marshall AJ, Beehler B. 2012. Ekologi Papua. Yayasan Obor, Jakarta. [Indonesian]

Manangkalangi E, Rahardjo MF, Hadiaty RK, et al. 2019. Distribution and abundance of the Arfak rainbowfish, Melanotaenia arfakensis Allen, 1990 in Prafi River system, Manokwari, West Papua: Due to habitat degradation? IOP Conf Ser Earth Environ Sci 404 (1): 012043 DOI: 10.1088/1755-1315/404/1/012043

Mittermeier RA, Myers N, Tliomsen JB, Olivieri S. 1998. Biodiversity hotspots and major tropical wilderness areas: Approaches to setting conservation priorities. Conserv Biol 12: 516-520. DOI: 10.1046/j.1523-1739.1998.012003516.x

Murdjoko A, Djitmau DA, Ungirwalu A, et al. 2021a. Pattern of tree diversity in lowland tropical forest in Nikiwar, West Papua, Indonesia. Dendrobiology 85: 78-91. DOI: 10.12657/denbio.085.008

Murdjoko A, Marsono D, Sadono R, Hadisusanto S. 2016. Plant species composition and their conspecific association in natural tropical rainforest, South Papua. Biosaintifika J Biol Biol Educ 8 (1): 33-46. DOI: 10.15294/biosaintifika.v8i1.5217

Murdjoko A, Ungirwalu A, Mardiyadi Z, et al. 2021b. Floristic composition of buah hitam habitats in lowland tropical mixed forest of West Papua, Indonesia. Floresta e Ambient 28 (3): e20210042. DOI: 10.1590/2179-8087-FLORAM-2021-0042

Pattiselanno F. 2016. Traditional Ecological Knowledge. TEK in hunting: from culture to nature. $\mathrm{KnE}$ Soc Sci 1: 66-70. DOI: 10.18502/kss.v1i1.436

Pattiselanno F, Apituley JRM, Arobaya AYS, Koibur JF. 2019. Short communication: Using wildlife for local livelihood - Experiences from the bird's head Peninsula, West Papua, Indonesia. Biodiversitas 20 (7): 1839-1845. DOI: 10.13057/biodiv/d200708

Pattiselanno F, Krockenberger A. 2021. Road development and indigenous hunting in Tanah Papua: Connecting the facts for future wildlife conservation agendas. For Soc 5: 181-189. DOI: $10.24259 /$ fs.v5i1.12528 
Pattiselanno F, Lubis MI. 2014. Hunting at the Abun regional marine protected areas: A link between wildmeat and food security. HAYAT J Biosci 21 (4): 180-186. DOI: 10.4308/hjb.21.4.180

Pawera L, Łuczaj Ł, Pieroni A, Zbynek P. 2017. Traditional plan knowledge in the White Carpathians: ethnobotany of wild food plant and crop wild relatives in the Czech Republic. Hum Ecol 45 (5): $655-$ 671

Peterson D, Hanazaki N, Li F. 2019. Understanding canoe making as a process of preserving cultural heritage. Ethnobiol Lett 10 (1): 59-68. DOI: $10.14237 / \mathrm{ebl}$.10.1.2019.1363

Santos JA dos, Silveira AP, Gomes V dos S. 2019. Knowledge and use of the flora in a quilombola community of Northeastern Brazil. Floresta e Ambient 26. DOI: 10.1590/2179-8087.093217

Sutarno S, Qayim I, Muhadiono I, et al. 2017. Traditional knowledge on the animal utilization by The Hatam Tribe of Manokwari, West Papua Province. Biosaintifika J Biol Biol Educ 9 (3): 451-459. DOI: 10.15294/biosaintifika.v9i3.9441
Tawer P, Maturbongs R, Murdjoko A, et al. 2021. Vegetation dynamic post-disturbance in tropical rain forest of bird's head peninsula of West Papua, Indonesia. Ann Silvic Res 46: 48-58. DOI: 10.12899/ASR-2145

Ungirwalu A, Awang SA, Murdjoko A. 2014. Potensi Pengembangan Agroforestri Tumbuhan Buah Hitam Berbasis Pengetahuan Lokal Etnis Wandamen-Papua: Prospek Perhutanan Sosial Di Papua Barat. In: Prosiding Seminar Nasional Silvikultur II : Pembaharuan Silvikultur untuk mendukung Pemulihan Fungsi Hutan menuju Ekonomi Hijau. [Indonesian]

Ungirwalu A, Awang SA, Suryanto P, Maryudi A. 2017. The ethnotechno-conservation approach in the utilization of black fruit. Haplolobus sp.. by the Wandamen ethnic of Papua, Indonesia. Biodiversitas 18: 1336-1343. DOI: 10.13057/biodiv/d180408

Ungirwalu A, Awang SA, Suryanto P, Maryudi A. 2019. Small scale ecology and society: Forest-culture of Papua nutmeg. J Ilmu Kehutan 13: 114-126. [Indonesian] 